\title{
Clinical significance of Th17 cells in kidney transplantation
}

\author{
Byung Ha Chung ${ }^{1,2,3}$, Chul Woo Yang ${ }^{1,2,3}$, and Mi-La Cho ${ }^{1}$
}

\author{
${ }^{1}$ Convergent Research \\ Consortium for Immunologic \\ Disease, ${ }^{2}$ Transplant Research \\ Center, ${ }^{3}$ Division of Nephrology, \\ Department of Internal Medicine, \\ College of Medicine, Seoul St. Mary's \\ Hospital, The Catholic University of \\ Korea, Seoul, Korea
}

Received: March 7, 2018

Accepted: March 13, 2018

\section{Correspondence to}

Mi-La Cho, Ph.D.

Department of Internal Medicine, College of Medicine, Seoul St.

Mary's Hospital, The Catholic University of Korea, 222 Banpo-daero, Seocho-gu, Seoul 06591, Korea

Tel: $+82-2-2258-7467$

Fax: +82-2-599-4287

E-mail: iammila@catholic.ac.kr
Transplantation research has focused on cytotoxic T-cell and plasma cell/ B-cell-targeted strategies, but little attention has been paid to the role of $\mathrm{T}$ helper 17 (Th17) cells in allograft dysfunction. However, accumulating evidence suggests that Th17 cells contribute to the development of acute and chronic allograft injury after transplantation of various organs, including the kidney. This review summarizes recent reports on the role of Th17 cells in kidney transplantation. Means of improving allograft outcomes by targeting the Th17 pathway are also suggested.

Keywords: Allograft rejection; Chronic allograft dysfunction; Kidney transplantation; Mammalian target of rapamycin; Th17 cells

\section{INTRODUCTION}

Kidney transplantation (KT) is the best available treatment option for end-stage renal disease. However, the long-term success rate of KT is limited by acute or chronic allograft rejection due to progressive destruction caused by recognition of donor alloantigens by the recipient's immune system [1]. Allograft rejection after KT is mediated mainly by helper T-cells. The Th1-Th2 balance is regarded as the major mechanism of rejection [2]. However, certain immunologic events occurring after KT cannot be explained solely by the Th1-Th2 balance. Therefore, the mechanism of rejection has been expanded to include T helper 17 (Th17) cells, which secrete the proinflammatory cytokine interleukin 17 (IL-17) [3]. Th17 cells were identified as a subset distinct from $\mathrm{T}$ helper type 1 and 2 cells in 2005 [3-5]. Th17 cells were first found to be clinically important in autoimmune disorders, and are now of interest in transplantation [6-8]. Indeed, Th17 cells and their associated cytokines play an important role in the development of acute and chronic allograft injury after organ transplantation [1,8-12]. For example, IL-17 messenger RNA (mRNA) and protein levels are elevated in animal models of acute rejection [13]. In KT, the IL-17 mRNA level is elevated in proximal tubular epithelial cells from allograft tissue with subclinical rejection [14]. Moreover, the IL-17 protein level is elevated, and IL-17 mRNA is detectable, in kidney allografts with subclinical rejection [7]. Here, we review the findings on the role of Th17 cells in the development of acute or chronic rejection in KT, and discuss strategies to control the Thry pathway. 


\section{OVERVIEW OF TH17 CELLS}

Th17 cells secrete IL-17, which recruits monocytes and neutrophils and acts in synergy with other proinflammatory cytokines [3]. Transforming growth factor $\beta$, IL-6, and IL-1 $\beta$ mediate the induction of immature Th17 cells $[15,16]$. However, they have a different nuclear transcript factor profile compared to classical Th1 cells; i.e., ROR $\gamma \mathrm{t}$ (RAR-related orphan receptor $\gamma \mathrm{t}$ ) and signal transducer and activator of transcription $3\left(\mathrm{STAT}_{3}\right)[3,17]$. Finally, differentiation into effector Th17 cells is mediated by the IL-23-IL-23R interaction [18]. Mature Th17 cells produce IL-22, express C-C motif chemokine receptor (CCR)-6, -4, and -10, and do not produce IL-10 (Fig. 1) [19-21].

\section{TH17 CELLS IN KIDNEY ALLOGRAFT TISSUE WITH ACUTE ALLOGRAFT REJECTION}

Acute allograft rejection is initiated by alloreactive T-cells primed in secondary lymphoid organs and recruited to the graft. The production of various proinflammatory cytokines by infiltrating cells is increased during acute kidney allograft rejection [22-24]. Therefore, diagnosis and staging of allograft rejection are based on the severity or pattern of immune cell infiltration and evidence of local immune system activation in allograft tissue [25-28]. Increased expression of IL-17 in local tissue is associated with allograft rejection in vivo $[7,14,29]$. Also, greater infiltration of Th17 cells compared to $\mathrm{FOXP}_{3}{ }^{+}$(forkhead box $\mathrm{P}_{3}^{+}$) regulatory T-cells (Tregs) is associated with both the severity of T-cell-mediated rejection (TCMR) and the subsequent clinical prognosis. A lower Treg/Th17 infiltration ratio is significantly associated with reduced allograft function and more severe interstitial and tubular injury [26]. Also, greater infiltration of Th17 cells is significantly associated with steroid-resistant rejection, incomplete recovery, recurrent TCMR, and a lower allograft survival rate after rejection. Several mechanisms have been suggested to underlie the above. First, renal epithelial cells exposed to IL-17 produce inflammatory mediators that stimulate early alloimmune responses [13]. Second, IL-17 induces neutrophil recruitment during severe rejection, as seen in biopsies [30]. Third, Th17 cells drive alloimmune responses by promoting lymphoid neogenesis [12]. Thus, Th17 cells induce stronger and more sustained alloimmune responses, which can result in severe injury to allograft tissue.

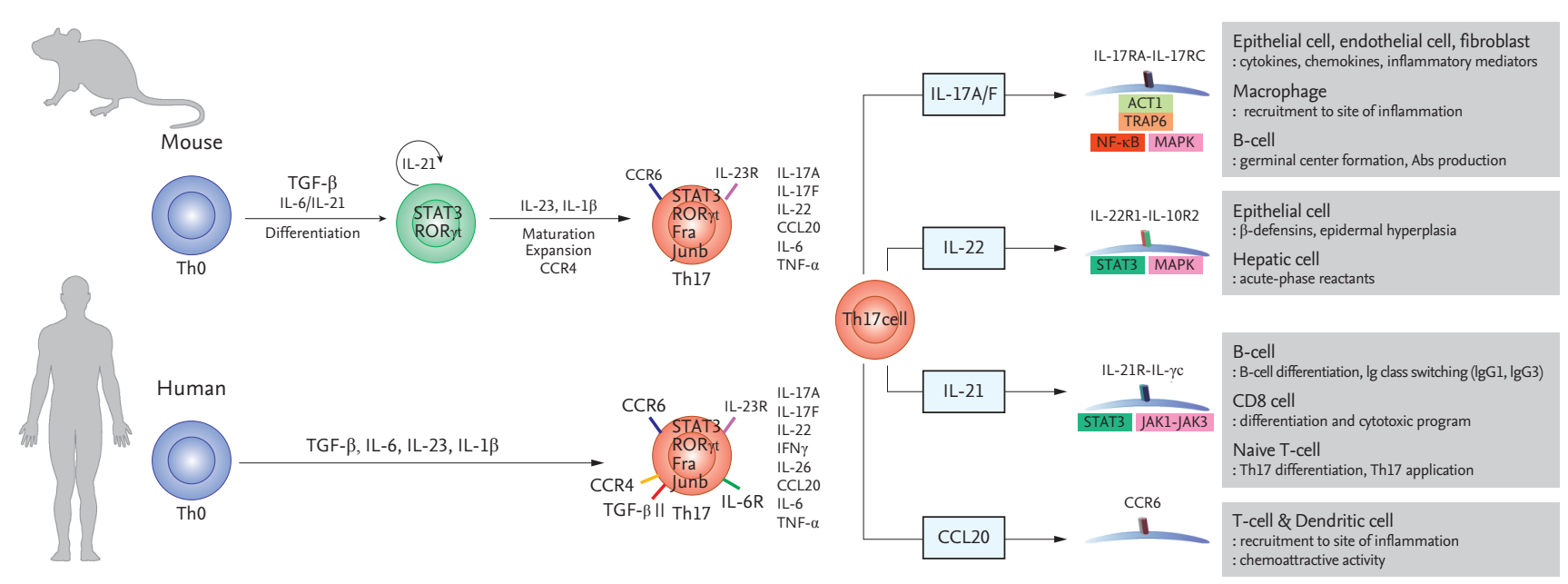

Figure 1. Differentiation of T helper 17 (Th17) cells in mice and humans and the functions of Th17 cytokines and chemokines. Th17 cells secrete interleukin 17A/F (IL-17A/F), interleukin 22 (IL-22), interleukin 21 (IL-21), and C-C motif chemokine ligand 20 (CCL2O), which modulate inflammation and immune cell recruitment. TGF- $\beta$, transforming growth factor $\beta$; STAT3, signal transducer and activator of transcription 3; ROR $\gamma$ t, RAR-related orphan receptor $\gamma \mathrm{t}$; CCR, C-C motif chemokine receptor; ACT1, actin 1; TRAP6, thrombin receptor-activating peptide-6; NF- $\mathrm{B}$, nuclear factor $\kappa \mathrm{B}$; MAPK, mitogen-activated protein kinase; IgG, immunoglobulin G. 


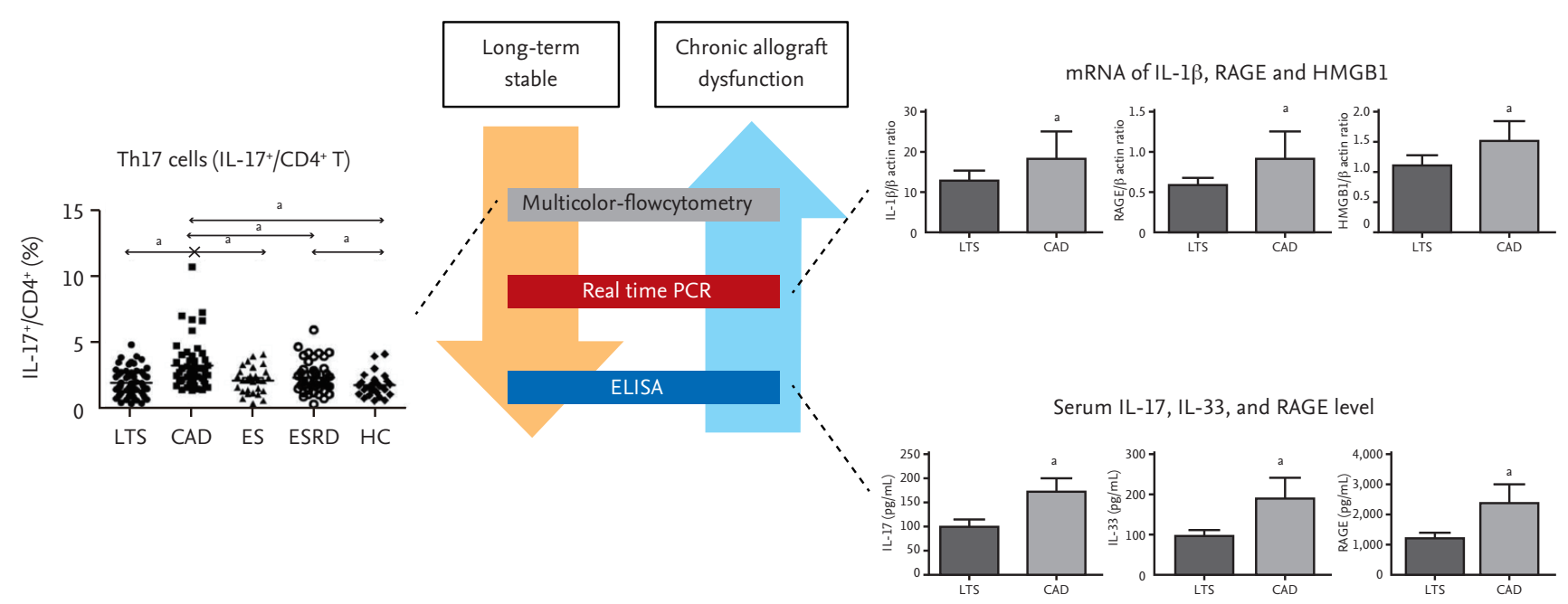

Figure 2. Activation of the T helper 17 (Th17) pathway in kidney transplantation recipients with chronic allograft dysfunction (CAD). The proportion of Th17 cells (interleukin $17^{+}\left[\mathrm{IL}-17^{+}\right]$/cluster of differentiation $4^{+}\left[\mathrm{CD}_{4}^{+}\right]$); the IL-1 $\beta$, receptor for advanced glycation end products (RAGE), and high mobility group box 1 (HMGB-1) messenger RNA (mRNA) levels; and the IL17, interleukin 33 (IL-33), and RAGE levels in peripheral blood are higher in patients with CAD. Modified from Chung et al. [41]. LTS, long-term stable; ES, early stable; ESRD, end stage renal disease; HC, healthy control; PCR, polymerase chain reaction; ELISA, enzyme-linked immunosorbent assay. ${ }^{a} p<0.05$ for each comparison.

\section{ROLE OF TH17 CELLS IN CHRONIC KIDNEY ALLOGRAFT DYSFUNCTION}

Th17 cells may be associated with severe allograft rejection. Therefore, we investigated whether Th17 cells are involved in chronic allograft dysfunction (CAD), which is the main cause of allograft failure. In human proximal renal tubular epithelial cells (HPRTEpiCs), IL-17 not only increases the production of markers of acute inflammation (IL-6 and IL-8) but also modulates the expression of profibrotic markers; e.g., CTGF (connective tissue growth factor) and ACTA-2 ( $\alpha$-actin 2) [31-33]. The proportion of peripheral blood Th17 cells from KT recipients with CAD was significantly increased in comparison to those of KT recipients with stable allograft function, irrespective of follow-up duration. Interestingly, the proportion of Th17 cells was higher in CAD patients than in transplant-naïve chronic kidney disease (CKD) patients, although renal function was lower in the CKD patients. This is important because uremia itself can increase the proportion of IL-17-producing effector T-cells [34]. Our results suggest that the immune response rather than renal dysfunction is responsible for the increased proportion of Th17 cells in patients with CAD (Fig. 2) [33].

\section{EFFECTS OF IMMUNOSUPPRESSIVE AGENTS ON TH17 CELLS}

The incidence of early allograft loss due to acute rejection can be significantly reduced by use of immune suppressants [35]. T-cells are suppressed by treatment with a combination of tacrolimus (Tac), mycophenolate mofetil, and steroid. In addition, induction therapy using basiliximab, an anti-CD25 monoclonal antibody, suppresses the proliferation of T-cells [1]. Although maintenance immune suppression can improve the allograft survival rate in the first year after KT, there has been little improvement in the long-term outcomes [36], suggesting that the currently used immune-suppressant regimen has limitations. Tac, the major immune-suppressant used in KT recipients, blocks Th1- and Th2-associated alloimmune responses [37-39]. In contrast, few animal studies have investigated the effect of calcineurin inhibitors (CNIs) on Thi7 responses. In an animal model of heart transplantation, CNI did not suppress the Th17-associated response [40]. Both Th1 and Th2 cytokines are required to reduce the IL-17 level, while administration of an anti-Th1 or -Th2 cytokine antibody increases the IL-17 level [3]. Therefore, administration of Tac may actually enhance the Th17 response. Inter- 
estingly, the percentage of Th17 cells and production of IL-17 by effector memory T-cells $\left(\mathrm{T}_{\mathrm{EM}}\right)$ are significantly $(p<0.05)$ increased at 3 months after KT compared to baseline, whereas the proportions of Th1/Th2 cells and $\mathrm{T}_{\mathrm{EM}}$ cells are decreased in the early post-transplantation period [41]. In addition, Tac suppresses Th1 and Th2 cells in a concentration-dependent manner, but even a high concentration has no effect on Th17 cells in vitro [41]. This suggests that Tac-based immunosuppression may be inadequate to suppress Th17 cells in KT recipients.

\section{STRATEGIES TARGETING TH17 CELLS}

\section{mTOR inhibitors}

Activation of Th17 cells is related to more severe allograft rejection and subsequent adverse outcomes $[26,42]$. In addition, an increased proportion of Th17 cells in peripheral blood is associated with CAD [33]. Therefore, modulation of the Th17 response may improve allograft outcomes in KT. Mammalian target of rapamycin (mTOR) is an important regulator of helper T-cell differentiation [4347]. Cluster of differentiation $4^{+}\left(\mathrm{CD}_{4}{ }^{+}\right)$T-cells lacking or deficient in mTOR fail to differentiate into effector cells or Treg cells under appropriate conditions $[48,49]$. Also, mTOR inhibition abrogates the reprogramming of Treg cells into pathogenic Th1/Th17 effector cells [50]. Sirolimus (SRL), an mTOR inhibitor, suppresses Th17 cells in KT recipients [50,51]. Moreover, conversion from Tac to SRL inhibits the proliferation of allogeneic $\mathrm{CD}_{4}{ }^{+} \mathrm{T}$-cells and Th17 cells in vitro and ex vivo [52].

\section{Regulation of Th17 cells by $1 \alpha, 25$-dihydroxyvitamin $D_{3}$}

Another strategy to regulate Th17 cells is to compensate Tac instead of conversion to mTOR inhibitor. Metabolic regulators, such as vitamin $\mathrm{D}$, have therapeutic effects on immunologic disorders that involve the Th17 response [53-55]. Indeed, a low serum 25-hydroxyvitamin D (25-[OH]D) level is associated with high Th17 activity in patients with autoimmune diseases or graft-versus-host disease after hematopoietic stem-cell transplantation. Furthermore, treatment with 10,25-dihydroxyvitamin $\mathrm{D}_{3}\left(1,25[\mathrm{OH}]_{2} \mathrm{D}_{3}\right)$ ameliorates these disorders by modulating the Th17 response [53,56-58] through suppression of the mTOR/STAT3 pathway [57,59,60]. Indeed, addition of $1,25(\mathrm{OH})_{2} \mathrm{D}_{3}$ to Tac significantly inhibits Th17

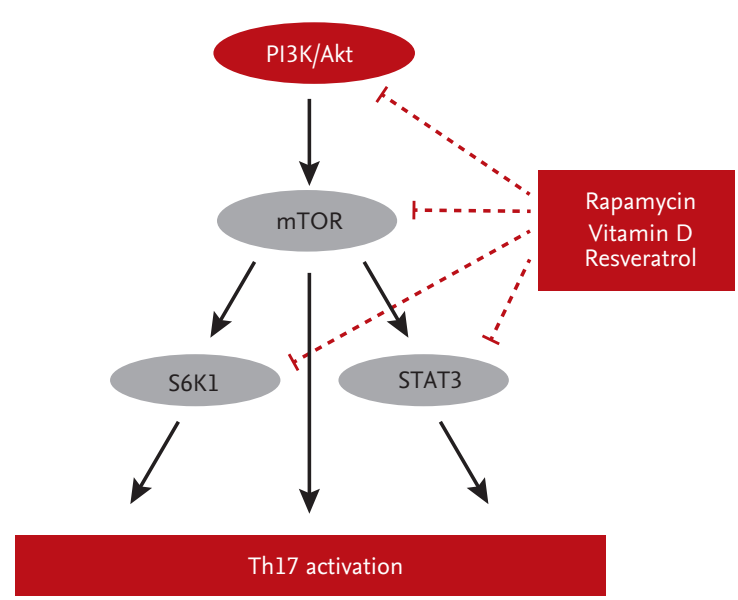

Figure 3. Effects of mammalian target of rapamycin (mTOR) inhibitors on the mTOR/signal transducer and activator of transcription 3 (STAT3) signaling pathway in T helper 17 (Th17) cells. $\mathrm{PI}_{3} \mathrm{~K}$, phosphoinositide 3-kinase; $\mathrm{S} 6 \mathrm{~K} 1$, ribosomal protein S6 kinase beta-1.

cells in vitro and reduces the IL-17 and IL-22 mRNA levels in peripheral blood mononuclear cells [61]. In Jurkat cells, the mTOR/STAT3 pathway is downregulated by the addition of $1,25(\mathrm{OH})_{2} \mathrm{D}_{3}$ to Tac [61]. In an ex vivo study, treatment with $1,25(\mathrm{OH})_{2} \mathrm{D}_{3}$ for 6 months significantly decreased the Thit level compared to baseline in 42 KT recipients [61]. Furthermore, resveratrol regulates the Th17 pathway by activating AMPK and suppressing mTOR (unpublished data). mTOR-targeted therapy suppresses Th17-related immune responses in KT recipients (Fig. 3).

\section{CONCLUSIONS}

This review summarizes the role of Th17 cells in KT. The Th17 pathway plays an important role in various types of allograft injury. Tac-based immunosuppression has a limited impact on Th17-cell-induced allograft injury. Several recent studies, including ours, suggest that mTOR-targeted strategies could suppress the Th17 pathway, but the clinical relevance is unclear. Therefore, development of strategies targeting the Thr pathway is required to improve allograft outcomes.

\section{Conflict of interest}

No potential conflict of interest relevant to this article was reported.] 


\section{REFERENCES}

1. Halloran PF. Immunosuppressive drugs for kidney transplantation. N Engl J Med 2004;351:2715-2729.

2. Liu Z, Fan H, Jiang S. CD4(+) T-cell subsets in transplantation. Immunol Rev 2013;252:183-191.

3. Park $\mathrm{H}$, Li Z, Yang XO, et al. A distinct lineage of $\mathrm{CD}_{4} \mathrm{~T}$ cells regulates tissue inflammation by producing interleukin 17. Nat Immunol 2005;6:1133-1141.

4. Harrington LE, Hatton RD, Mangan PR, et al. Interleukin 17-producing $\mathrm{CD}_{4}+$ effector $\mathrm{T}$ cells develop via a lineage distinct from the $\mathrm{T}$ helper type 1 and 2 lineages. Nat Immunol 2005;6:1123-1132.

5. Wynn TA. $\mathrm{T}(\mathrm{H})$-17: a giant step from $\mathrm{T}(\mathrm{H})_{1}$ and $\mathrm{T}(\mathrm{H})_{2}$. Nat Immunol 2005;6:1069-1070.

6. Loong CC, Lin CY, Lui WY. Expression of interleukin-17 as a predictive parameter in acute renal allograft rejection. Transplant Proc 2000;32:1773.

7. Hsieh HG, Loong CC, Lui WY, Chen A, Lin CY. IL-17 expression as a possible predictive parameter for subclinical renal allograft rejection. Transpl Int 2001;14:287-298.

8. Mitchell P, Afzali B, Lombardi G, Lechler RI. The T helper 17-regulatory $\mathrm{T}$ cell axis in transplant rejection and tolerance. Curr Opin Organ Transplant 2009;14:326-331.

9. Calvo-Turrubiartes M, Romano-Moreno S, Garcia-Hernandez M, et al. Quantitative analysis of regulatory T cells in kidney graft recipients: a relationship with calcineurin inhibitor level. Transpl Immunol 2009;21:43-49.

10. Warrens AN. Pharmacological control of the immune response in renal transplantation. BJU Int 2002;90:784-791.

11. Crispim JC, Grespan R, Martelli-Palomino G, et al. Interleukin-17 and kidney allograft outcome. Transplant Proc 2009;41:1562-1564.

12. Deteix C, Attuil-Audenis V, Duthey A, et al. Intragraft Th17 infiltrate promotes lymphoid neogenesis and hastens clinical chronic rejection. J Immunol 2010;184:5344-5351.

13. Loong CC, Hsieh HG, Lui WY, Chen A, Lin CY. Evidence for the early involvement of interleukin 17 in human and experimental renal allograft rejection. J Pathol 2002;197:322-332.

14. Van Kooten C, Boonstra JG, Paape ME, et al. Interleukin-17 activates human renal epithelial cells in vitro and is expressed during renal allograft rejection. J Am Soc Nephrol 1998;9:1526-1534.

15. Veldhoen M, Hocking RJ, Atkins CJ, Locksley RM, Stockinger B. TGFbeta in the context of an inflammatory cytokine milieu supports de novo differentiation of IL-17-producing T cells. Immunity 2006;24:179-189.

16. Bettelli E, Carrier Y, Gao W, et al. Reciprocal developmental pathways for the generation of pathogenic effector TH17 and regulatory T cells. Nature 2006;441:235-238.

17. Ivanov II, McKenzie BS, Zhou L, et al. The orphan nuclear receptor RORgammat directs the differentiation program of proinflammatory IL-17+ T helper cells. Cell 2006;126:1121-1133.

18. Kuchroo VK, Awasthi A. Emerging new roles of Th17 cells. Eur J Immunol 2012;42:2211-2214.

19. Van Voorhis M, Fechner JH, Zhang X, Mezrich JD. The aryl hydrocarbon receptor: a novel target for immunomodulation in organ transplantation. Transplantation 2013;95:983-990.

20. Singh SP, Zhang HH, Foley JF, Hedrick MN, Farber JM. Human T cells that are able to produce IL-17 express the chemokine receptor CCR6. J Immunol 2008;180:214-221.

21. Wilson NJ, Boniface K, Chan JR, et al. Development, cytokine profile and function of human interleukin 17-producing helper T cells. Nat Immunol 2007;8:950-957.

22. Merville P, Pouteil-Noble C, Wijdenes J, Potaux L, Touraine JL, Banchereau J. Cells infiltrating rejected human kidney allografts secrete IFN-gamma, IL-6, and IL-10, and are modulated by IL-2 and IL-4. Transplant Proc 1993;25(1 Pt 1):111-113.

23. Merville P, Pouteil-Noble C, Wijdenes J, Potaux L, Touraine JL, Banchereau J. Detection of single cells secreting IFN-gamma, IL-6, and IL-10 in irreversibly rejected human kidney allografts, and their modulation by IL-2 and IL-4. Transplantation 1993;55:639-646.

24. Pavlakis M, Strehlau J, Lipman M, Shapiro M, Maslinski W, Strom TB. Intragraft IL-15 transcripts are increased in human renal allograft rejection. Transplantation 1996;62:543-545.

25. Solez K, Colvin RB, Racusen LC, et al. Banff o7 classification of renal allograft pathology: updates and future directions. Am J Transplant 2008;8:753-760.

26. Chung BH, Oh HJ, Piao SG, et al. Higher infiltration by Th17 cells compared with regulatory $\mathrm{T}$ cells is associated with severe acute T-cell-mediated graft rejection. Exp Mol Med 2011;43:630-637.

27. Stegall MD, Chedid MF, Cornell LD. The role of complement in antibody-mediated rejection in kidney transplantation. Nat Rev Nephrol 2012;8:670-678.

28. Mauiyyedi S, Pelle PD, Saidman S, et al. Chronic humoral 
rejection: identification of antibody-mediated chronic renal allograft rejection by $\mathrm{C}_{4} \mathrm{~d}$ deposits in peritubular capillaries. J Am Soc Nephrol 2001;12:574-582.

29. Vanaudenaerde BM, Dupont LJ, Wuyts WA, et al. The role of interleukin-17 during acute rejection after lung transplantation. Eur Respir J 2006;27:779-787.

30. Healy DG, Watson RW, O'Keane C, et al. Neutrophil transendothelial migration potential predicts rejection severity in human cardiac transplantation. Eur J Cardiothorac Surg 2006;29:760-766.

31. Gore-Hyer E, Shegogue D, Markiewicz M, et al. TGF-beta and CTGF have overlapping and distinct fibrogenic effects on human renal cells. Am J Physiol Renal Physiol 2002;283:F707-F716.

32. LeBleu VS, Taduri G, O'Connell J, et al. Origin and function of myofibroblasts in kidney fibrosis. Nat Med 2013;19:1047-1053.

33. Chung BH, Kim KW, Kim BM, Doh KC, Cho ML, Yang CW. Increase of Th17 cell phenotype in kidney transplant recipients with chronic allograft dysfunction. PLoS One 2015;10:e0145258.

34. Chung BH, Kim KW, Sun IO, et al. Increased interleukin-17 producing effector memory $\mathrm{T}$ cells in the end-stage renal disease patients. Immunol Lett 2012;141:181-189.

35. Meier-Kriesche HU, Schold JD, Srinivas TR, Kaplan B. Lack of improvement in renal allograft survival despite a marked decrease in acute rejection rates over the most recent era. Am J Transplant 2004;4:378-383.

36. Guerra G, Srinivas TR, Meier-Kriesche HU. Calcineurin inhibitor-free immunosuppression in kidney transplantation. Transpl Int 2007;20:813-827.

37. Rentenaar RJ, van Diepen FN, Meijer RT, et al. Immune responsiveness in renal transplant recipients: mycophenolic acid severely depresses humoral immunity in vivo. Kidney Int 2002;62:319-328.

38. Takatsuki M, Uemoto S, Inomata Y, et al. Analysis of alloreactivity and intragraft cytokine profiles in living donor liver transplant recipients with graft acceptance. Transpl Immunol 2001;8:279-286.

39. Weimer R, Melk A, Daniel V, Friemann S, Padberg W, Opelz G. Switch from cyclosporine A to tacrolimus in renal transplant recipients: impact on Th1, Th2, and monokine responses. Hum Immunol 2000;61:884-897.

40. Syrjala SO, Keranen MA, Tuuminen R, et al. Increased Th17 rather than Th1 alloimmune response is associated with cardiac allograft vasculopathy after hypother- mic preservation in the rat. J Heart Lung Transplant 2010;29:1047-1057.

41. Chung BH, Kim KW, Kim BM, et al. Dysregulation of Th17 cells during the early post-transplant period in patients under calcineurin inhibitor based immunosuppression. PLoS One 2012;7:e42011.

42. Chung BH, Oh HJ, Piao SG, et al. Clinical significance of the ratio between FOXP3 positive regulatory $\mathrm{T}$ cell and interleukin-17 secreting cell in renal allograft biopsies with acute T-cell-mediated rejection. Immunology 2012;136:344-351.

43. Delgoffe GM, Pollizzi KN, Waickman AT, et al. The kinase mTOR regulates the differentiation of helper $\mathrm{T}$ cells through the selective activation of signaling by $\mathrm{MTORC1}$ and mTORC2. Nat Immunol 2011;12:295-303.

44. Zeiser R, Leveson-Gower DB, Zambricki EA, et al. Differential impact of mammalian target of rapamycin inhibition on $\mathrm{CD}_{4}+\mathrm{CD}_{25}+\mathrm{Foxp}_{3}+$ regulatory $\mathrm{T}$ cells compared with conventional $\mathrm{CD}_{4}+\mathrm{T}$ cells. Blood 2008;111:453-462.

45. Flechner SM, Kurian SM, Solez K, et al. De novo kidney transplantation without use of calcineurin inhibitors preserves renal structure and function at two years. Am J Transplant 2004;4:1776-1785.

46. Larson TS, Dean PG, Stegall MD, et al. Complete avoidance of calcineurin inhibitors in renal transplantation: a randomized trial comparing sirolimus and tacrolimus. Am J Transplant 2006;6:514-522.

47. Hackstein H. Rapamycin and dendritic cells: keep on movin'. Transplantation 2006;82:739-740.

48. Delgoffe GM, Kole TP, Zheng Y, et al. The mTOR kinase differentially regulates effector and regulatory $\mathrm{T}$ cell lineage commitment. Immunity 2009;30:832-844.

49. Chi $\mathrm{H}$. Regulation and function of $\mathrm{mTOR}$ signalling in $\mathrm{T}$ cell fate decisions. Nat Rev Immunol 20120;12:325-338.

50. Yurchenko E, Shio MT, Huang TC, et al. Inflammation-driven reprogramming of $\mathrm{CD}_{4}+$ Foxp3 3 regulatory $\mathrm{T}$ cells into pathogenic $\mathrm{Th} / \mathrm{Th} 1 \mathrm{~T} \mathrm{~T}$ effectors is abrogated by mTOR inhibition in vivo. PLoS One 2012;7:e35572.

51. Li Y, Shi Y, Huang Z, et al. CNI induced Th17/Treg imbalance and susceptibility to renal dysfunction in renal transplantation. Int Immunopharmacol 2011;11:2033-2038.

52. Kim KW, Chung BH, Kim BM, Cho ML, Yang CW. The effect of mammalian target of rapamycin inhibition on $\mathrm{T}$ helper type 17 and regulatory $\mathrm{T}$ cell differentiation in vitro and in vivo in kidney transplant recipients. Immunology 2015;144:68-78. 
53. Mora JR, Iwata M, von Andrian UH. Vitamin effects on the immune system: vitamins A and D take centre stage. Nat Rev Immunol 2008;8:685-698.

54. Peelen E, Knippenberg S, Muris AH, et al. Effects of vitamin D on the peripheral adaptive immune system: a review. Autoimmun Rev 2011;10:733-743.

55. Baeke F, Takiishi T, Korf H, Gysemans C, Mathieu C. Vitamin D: modulator of the immune system. Curr Opin Pharmacol 2010;10:482-496.

56. Smolders J, Menheere P, Thewissen M, et al. Regulatory T cell function correlates with serum 25 -hydroxyvitamin $\mathrm{D}$, but not with 1,25-dihydroxyvitamin $\mathrm{D}$, parathyroid hormone and calcium levels in patients with relapsing remitting multiple sclerosis. J Steroid Biochem Mol Biol 2010;121:243-246.

57. Datta Mitra A, Raychaudhuri SP, Abria CJ, et al. 1 $\alpha, 25$-Dihydroxyvitamin-D3-3-bromoacetate regulates AKT/mTOR signaling cascades: a therapeutic agent for psoriasis. J Invest Dermatol 2013;133:1556-1564.

58. Ranganathan P, Khalatbari S, Yalavarthi S, Marder W, Brook R, Kaplan MJ. Vitamin D deficiency, interleukin 17, and vascular function in rheumatoid arthritis. J Rheumatol 2013;40:1529-1534.

59. Lisse TS, Hewison M. Vitamin D: a new player in the world of mTOR signaling. Cell Cycle 2011;10:1888-1889.

6o. Lisse TS, Liu T, Irmler M, et al. Gene targeting by the vitamin $\mathrm{D}$ response element binding protein reveals a role for vitamin D in osteoblast mTOR signaling. FASEB J 2011;25:937-947.

61. Chung BH, Kim BM, Doh KC, et al. Suppressive effect of 1 $\alpha, 25$-dihydroxyvitamin $\mathrm{D}_{3}$ on Th17-immune responses in kidney transplant recipients with tacrolimus-based immunosuppression. Transplantation 2017;101:1711-1719. 